\title{
A nagyváros szélén: A városi terjeszkedés térbeli társadalmi problémái
}

\author{
On the edge of a large city: the spatial and \\ social issues of urban sprawl
}

\author{
SZIRMAI VIKTÓRIA
}

KULCSSZAVAK: városi terjeszkedés, elővárosok, város és környék dichotómia

\begin{abstract}
ABSZTRAKT: A tanulmány a városterjeszkedés problémáját vizsgálja mindenekelőtt nemzetközi kontextusban, amelyböl kiderülnek a fejlett nyugati társadalmak nagyvárosi térségeinek belső társadalmi egyenlőtlenségei, azok modern formái, a felsőés középosztálybeliek, valamint a hátrányos társadalmi helyzetǔek által lakott elővárosok társadalmi problémái. Ezł követően a tanulmány a budapesti várostérségben érzékelhető területi terjeszkedés folyamatát tárja fel, két konkrét empirikus vizsgálat segítségével leírja a város és a környék között ma jellemző ellentmondásokat, azok átalakulásait, a városkörnyéken létrejött magasabb státusú, valamint az alacsonyabb ökológiai és társadalmi pozíciójú települések dichotómiáit. Ezek szerint a fejlett városkörnyéki települések népességének magasabb a jövedelme, jobb az iskolázottsága, miközben a fejletlenebb városkörnyéki településeken élők kevésbé iskolázottak, alacsonyabb, illetve közepes a jövedelmük. A cikk bemutatja a város és a különböző fejlettségú környékbeli települések viszonyát, a városterjeszkedéssel összefüggő helyi konfliktusokat, a szuburbanizáció okozta ellentmondásokat, a kialakult viszonyt meghatározó folyamatokat is.
\end{abstract}

\section{KEYWORDS: urban sprawl, suburbs, dichotomy of city and suburb}

ABSTRACT: The article analyses the phenomena associated with urban sprawl in the international context, revealing the inner social inequalities in developed Western European urban regions, their modern manifestations and the social problems of higher and middle class people and the social problems of outskirt areas populated by people in a disadvantageous social situation. Next, it also presents the urban sprawl processes in the case of the Budapest region, based on the results of two significant empirical surveys. The findings verified some current regional inequalities between the city and the suburban areas, the dichotomies of developed and underdeveloped suburbs. According to these, the population of developed suburban areas has higher income and better education, while people living in less developed suburban areas are less educated and have lower or medium income. The relationship between the city and the neighbouring settlements of different

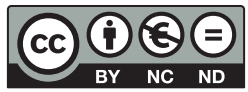


developmental levels, the local conflicts related to urban sprawl, the contradictions caused by suburbanisation, the processes responsible for the established relationships are also presented.

\section{A városi terjeszkedés problematikája}

Az amerikai középosztály által lakott elővárosok elidegenedett légkörét, sekélyes kapcsolatait, az amerikai álom és családmodell sikertelenségének területi megnyilvánulásait szemléletesen mutatják be Edward Elbeenek az 1960-as években írt drámái, a „Nem félünk a farkastól”, a „Mindent a kertbe” vagy a „Kényes egyensúly”. Az európai, közte a francia elővárosok bizonyos típusainak problémáit, az elővárosi bűnözést, az erőszakot, a félelmet a filmművészet területéről kiragadott művek is kiválóan érzékeltetik, például a Mathieu Kassovitz rendezte „Gyülölet” (La Haine) vagy Luc Besson „B13-Bünös negyed" (Banlieue 13) címü filmjei.

Az európai elővárosok természetesen különböznek az amerikaiaktól, részben a városfejlődési sajátosságok, a társadalomszerkezeti különbségek, részben a társadalmi feszültségek jellegzetességei miatt. Az amerikai elővárosokban a középosztálybeli életforma önmagát kiteljesítő bezártsága és individualizmusa, az európai esetekben pedig a hátrányos társadalmi helyzetüek koncentrációja, a társadalmi kirekesztés adja a fó társadalmi és politikai gondot, jóllehet itt is megtalálható a középosztálybeli elővárosi jelenségek sora, meg az individualizáció is. Az elővárosok, illetve az úgynevezett „peri-urbaine” térségek terjedését eredményező „urban sprawl” folyamata (annak társadalmi hatásaival) azonban mindenképpen közös bennük.

A városi terjeszkedést erőteljesen bírálja a nemzetközi szakirodalom. A kritikák az urbanizált, egyben kontrollálatlanul növekvő területek problémáit, a rurális térségek visszaszorulását, a mezőgazdasági területek, az erdők csökkenését, a zöld területek fogyását emelik ki. Szinte minden bírálat rámutat az erőteljes motorizáció környezeti ártalmaira, a lakó- és a munkahely közötti időigényes utazások egészségügyi hatásaira, a lakóhelyváltással összefüggő radikális életmódváltás negatív következményeire (Frumkin 2002). A kedvezőtlen gazdasági hatásokat, a gazdaság dinamizmusát is fékező infrastrukturális - közte úthálózat-fejlesztési - igények kielégítésének költségeit is felveti Williamson, Imbroscio és Alperovitz (2005). A polgároknak a belvárosi környezeti ártalmak és a szegénység látható jelei miatt a városkörnyékre menekülése, a radikálisan csökkenő nagyvárosi lakosságszám, a hagyományos kompakt város eltűnése is az aggodalmak között szerepel (Munoz 2003).

A területi terjeszkedésben átalakuló nagyvárostérségi társadalmak új szerkezeti jellegzetességeit, a felső- és középosztálybeliek által benépesített 
lakóparkok szegregációját és mindezek kedvezőtlen városi hatásait (Le Goix 2004), de a városkörnyéki társadalmi kirekesztést is komoly bírálatok illetik. Európában egy újféle térbeli társadalmi dichotómia szerveződése, a város-vidék ellentét helyett létrejött centrum és periféria, város és környék egyenlőtlensége okoz gondokat (Vieillard-Baron 2008). A társadalmi kirekesztés legszélsőségesebb példáit a harmadik világ - Afrika, Dél-Amerika, Brazília, India vagy éppen Kína - elképesztő méretü, teljes mértékben kontrollálatlan városnövekedése hozza, ahol a városok szélén, a perifériákon létrejött slumok sokaságában embertelen körülmények között élnek a szegények legszegényebbjei (Davis 2007).

Nem mindenki vitatja a városnövekedés jelentőségét. Főként azért nem, mert tudomásul veszik a szuburbán környezet iránti társadalmi igényeket, azt, hogy egyre többen vannak, akik a lakóhelyválasztáskor a városkörnyéket részesítik előnyben. Sokan gondolják azt is, hogy az urban sprawl a városkörnyék fejlesztésének olyan eszköze, amelynek a segítségével a vidék urbanizálódik (Fishman 1990, Le Goaziou, Rojzman 2006, 10.).

A problémák megoldására mind a két tábor kínál eszközöket. A városnövekedést ellenzők a centralizált városfejlesztési modellek erősítését, a város belső területére kiterjedő fejlesztéseket, a magasabb és sűrűbb beépítést ajánlják. A városterjeszkedést pártolók a tömegközlekedés dinamikus fejlesztését, erőteljes tervezési beavatkozásokat sürgetnek.

Nem újak sem a viták, sem a megoldási javaslatok. A számos történeti példa közül talán a legjelentősebb Howard kertvároseszméje, amely a 19. század - sokak szerint a mai napig érvényes - tervezési beavatkozását kínálja. A nagyváros környékén épülő, de attól elkülönülő kertváros - mint egy kompakt település - lakó- és munkahelyet jelent, a szabadidő eltöltésének teljes körü feltételeit nyújtja, teljes mértékben integrálja az ott élőket, felszívja az eredetileg a nagyvárosba törekvőket, így megakadályozza a centrumtelepülés korlátlan növekedését (Howard 1902). A kertvárosi gondolat jegyében született bolygóvárosok, új városok, kertvárosi elővárosok - bár számos európai nagyváros esetében kísérelték meg a túlzott mértékủ terjeszkedést megakadályozni, a népesség letelepedését meghatározott irányokba terelni - soha nem voltak igazán sikeresek. A kertvárosi eszme relevanciáját, a tervek megvalósulását, vagyis a lakó- és a munkahely egységét hirdető térbeli közösségek kialakulását és hosszú távú fenntarthatóságát az európai esetekben a gazdaságot időközben átformáló új folyamatok írták felül. Az 1900-as évek elején még nem is igen érzékelhető, de később emberek tömegeit vonzó városi szolgáltatószektor dinamikus fejlődése, nem utolsósorban az életmódigények és -formák átalakulása, azok lokális jellegének enyhülése a globalizációs trendeknek is köszönhető (Szirmai 1988).

Egy másik példa az orosz avantgárd építészek két különböző felfogást képviselő csoportja, az urbanisták és a dezurbanisták 1929 és 1931 között zajló vitája. Az első csoport a koncentrált városfejlesztéssel, a másik tábor pedig 
a dekoncentrált, vagyis a szétszórt városfejlesztés modelljével képzelte az akkor érzékelhető nagyvárosi problémák enyhítését (Kopp 1979).

A korai megoldási javaslatok mai alkalmazhatóságát az újabb folyamatok teszik kétségessé. A Howard vagy éppen az avantgárd építészek által felvetett problémák és megoldási javaslatok óta az urbanizációs folyamatok és hatásaik radikális módon megváltoztak, többek között a globalizációs folyamatok dinamizálódása miatt is. A történeti viták az urbanizáció első szakaszaiban zajlottak, az akkori városnövekedés, a felgyorsult városba áramlás vagy már az éppen kibontakozó szuburbanizáció idején. Természetesen a jelzett periódusok térbeli társadalmi problémái is súlyosak voltak, de eltérőek a mai folyamatoktól, a globalizáció előretörésének hatásaitól, amely mögött ma már szinte tudományos közhelynek számító nagy mechanizmusok húzódnak. Egyrészt a fejlett nyugateurópai országokban (az Amerikai Egyesült Államokban és Japánban is) megfigyelhető az erőteljes gazdasági és társadalmi centralizáció, a szolgáltatószektor, a szakképzett munkaerő nagyvárosi koncentrációja, a multinacionális, a transznacionális vállalatok előretörése és ennek hatására a nagyvárosok s perifériájuk erőteljes fejlődése (Veltz 1996, 33.). Másrészt megfigyelhető a nagyvárosi régióknak a világ gazdaságában betöltött központi szerepe.

A gazdaság, illetve a népesség egyre erősebb nagyvárosi koncentrációja a lakóhelyek és a munkahelyek dinamizálódó területi szétválásában, a lakóhelyeknek a munkahelyeknél is gyorsabb kifelé történő terjeszkedésében jelentkezett. Ez a tőkebefektetéseknek, az infrastrukturális fejlesztéseknek, a kereskedelmi és egyéb szolgáltatások kialakításának a centrumoktól kifelé irányuló térbeli rendjét határozta meg (Hall 1996). Az eredmény a városi agglomerációk területet fogyasztó térbeli expanziója, a rövid és hosszú távú ingázás mértékének emelkedése, a közlekedés iránti igény és a kapacitás növekedése, a környezeti károk kiterjedése, a térbeli társadalmi szerkezet átalakulása, vagyis az urban sprawl és hatásai. A nagyvárosi térségek mai területfogyasztási jelenségei mögött a fogyasztói társadalom értékrendjének térhódítása, a jólétben élők számának növekedése, az átalakult lakóhelyi igények is ott vannak.

Az 1950-es években az USA-ban 30 millió ember, a lakosság 19\%-a volt elővárosi lakos. ${ }^{1}$ Ez a szám az 1970-es, 1980-as években tovább nőtt. A tények szerint a trend folytatódik, az amerikai társadalom ma körülbelül fele él elővárosokban. A nagy amerikai világvárosokban² 1990 és 2000 között tovább csökkent a városi, és nőtt a városkörnyéki lakosság aránya. A városszéli népesség arányai jóval meghaladják a városi népesség arányait, az urbanizált térségeken elhelyezkedő népesség túlnyomó többsége a városkörnyékeken lakik.

Az európai trendek ettől azonban eltérőek. A nagy európai világvárosok esetében a városi népesség aránya számos esetben jóval meghaladja a városkörnyéki népesség arányait. (Ilyen például Berlin, Bécs, Brüsszel, London, Prága, Róma, Varsó és Budapest.) Vannak kivételek, például Koppenhága, ${ }^{3}$ de kiváltképp Párizs, ${ }^{4}$ ahol a városkörnyékeken jóval magasabb a népességarány. Mi- 
közben számos európai nagyvárostérség népességmegosztásában is érzékelhető változás, 1996 és 2004 között például Madrid, Berlin, Róma, Bécs, Varsó, Prága, Ljubljana esetében néhány százalékkal növekedett a városkörnyékiek aránya. A legjelentősebb növekedés Budapest környékén zajlott le. ${ }^{5}$ Ezért is fontos megvizsgálni az urban sprawl hazai folyamatait. Már csak azért is, mert miközben a világban a városi terjeszkedés egyre jellemzőbbé válik, a magyarországi városterjeszkedés folyamatait kevéssé ismerjük. ${ }^{6}$ Nem igazán tudjuk, hogy mi történik a magyar nagyvárosi térségekben. Érzékelhető-e a nagyvárosi terjeszkedés, $s$ ha igen, mindez milyen következményekkel jár? Ezzel összefüggésben hogyan alakul át a nagyvárosi tér társadalmi szerkezete, változnak-e a szegregációs sémák? A tanulmány ezekre a kérdésekre keresi a választ a budapesti városrégió példáján, a fóbb nemzetközi trendek keretében, két átfogó kutatás adatbázisán. Az egyik a 2004 és 2007 között végzett „Várostérségek, térbeli társadalmi egyenlőtlenségek és konfliktusok - Az európai versenyképesség térségi társadalmi tényezői" című kutatás. ${ }^{7}$ A másik a 2009 és 2011 között megvalósított, a „Fenntartható fogyasztás, termelés és kommunikáció. A modern fogyasztási modelleket meghatározó társadalmi mechanizmusok és érdekviszonyok. A fenntartható fogyasztás társadalmi és térbeli modellje" ${ }^{8}$ címü projekt. ${ }^{9}$

\section{Város és környék dichotómia a fejlett nyugati társadalmakban}

A francia társadalomban az utóbbi években kiemelt politikai és tudományos figyelmet kap az elővárosi probléma, amit a városkörnyéki népesség magas arányán túl a 2005-ös párizsi elővárosi megmozdulások, brutális tüntetések is magyaráznak. A francia többség számára a városkörnyékek, illetve inkább a városkörnyéki emberek a társadalmi deviancia megtestesítői. A francia kutatók szerint a negatív kép kialakulásában a média hatása kiemelten fontos, de tény az is, hogy néhány szakmacsoport tagjai, így az építészek, a kutatók, a politikusok igen kedvezőtlen vagy inkább egyoldalú képet mutattak a közvéleménynek elsőként a lakótelepekről, majd az elővárosokról is (Vieillard-Baron 2008).

A lakótelepekkel kapcsolatos társadalmi megbélyegzés kiindulópontja az úgynevezett „sarcessizmus”, vagyis az 1960-as években a Párizstól 15 km-re felépített új Sarcesses-Lochére negyeddel ${ }^{10}$ kapcsolatos kritika: az elszigeteltség, a gigantikus méretű ingerszegény épített környezet, az ott koncentrálódó bűnözés túlzott mértékủ hangsúlyozása volt. Pedig a korabeli vizsgálatok szerint a lakótelepi népesség jelentős része elégedettnek bizonyult a lakóhelyével, kivéve, ahol a bünözés valóban jelentős mértékünek mutatkozott (Vieillard-Baron 2008, 28.). A média hatása érzékelhető abban is, hogy az 1980-as évektől kezdve már nemcsak a lakótelepek, hanem az elővárosok is a társadalmi problémák gyüjtőterületeiként jelentek meg. 
Tényleges folyamatok is magyarázták a lakótelepekkel kapcsolatos negatív megközelítést (Le Goaziou, Rojzman 2006, 36.). A II. világháborút követő lakáshiány, majd a demográfiai robbanás, a baby-boom szükségleteire válaszolni kívánó új lakótelep-fejlesztések főként a középosztálybeliek számára okoztak elégedetlenséget, mivel alig nyújtották a szükséges lakóhelyi infrastruktúrát, a kis üzleteket és a (franciák számára oly fontos) kávéházakat, egyéb szabadidős szolgáltatásokat. A monoton épített környezetet sem kedvelték az emberek. Ezért többnyire a magasabb társadalmi státusúak az 1970es, 1980-as években már kezdték elhagyni az új negyedeket, és visszatértek az időközben megújult, megújuló városközpontokba, vagy a jó ökológiai és társadalmi pozíciójú környékbeli településekre, a jobb elővárosokba, az új városokba költöztek. Az 1960-as évek közepétől egyre több külföldről bevándorló települt (részben hatósági akaratra) a lakótelepekre, részben az észak- és nyugat-afrikai bevándoroltak által spontán létrehozott „bidon-ville”-ekből, bádogvárosrészekből.

Az 1960-as években a nagyvállalatok (elsősorban autógyárak) kisebb részben francia, nagyobb részben pedig az Észak-Afrikából, Algériából bevándorolt, szakképzetlen, iskolázatlan munkásaiknak is építettek Párizs környéki elővárosokat (Le Goaziou, Rojzman 2006, 21.). Az egykori bevándorlók második, harmadik generációi élnek itt, akik az első generációhoz hasonlóan szakképzetlenek, iskolázatlanok, többnyire munkanélküliek.

Az országban körülbelül 5 millió ember él az úgynevezett „érzékeny városi zónában" (Zones Urbaines Sensibles, ZUS ${ }^{11}$ ), a társadalmilag problematikus elővárosi térségekben. Az itt élők majdnem 40\%-a nem fejezi be iskoláit. Közülük kerül ki a mai munkanélküliek számottevő része. A 2009-es adatok szerint a 7,5\%-os országos átlaggal szemben $16,9 \%$ az elővárosi munkanélküliek aránya, ők fóként fiatalok, sok közöttük a férfi (Le Goaziou, Rojzman 2006, 24.; Bronner 2010, 9.).

A jövő bizonytalansága, a mindennapi megélhetés gondjai, a lakóhelyi társadalmi feszültségek számos konkrét konfliktus forrásai. Ellentmondások vannak az idősebb és a fiatalabb nemzedék között, aminek oka az idősebbek félelme az utcán „élő” és randalírozó fiatal bandáktól. Néha csendes, néha hangos viszályok alakulnak ki a munkában állók és a munkanélküliek között is, amelyek sok esetben etnikai problémává eszkalálódnak, pedig a lakóhelyi konfliktusok lényegében társadalmi strukturális ellentmondások a bevándoroltak vagy leszármazottjaik és a francia „oslakosság” - legfóképpen a kisebbségben lévő elővárosi alsó középosztálybeliek, középosztálybeliek és a többségben lévő underclass, a kirekesztettek - között.

Korántsem francia jelenség, hogy a városkörnyék meghatározott részei az alacsonyabb társadalmi státusúak lakóhelyei, illetve a városcentrumokból kirekesztett rétegek befogadói. A brüsszeli városrégióban lejátszódó folyamatok, az első generációs bevándorlóknak otthont adó régi városcentrumot környező részek felújítása következtében a peremterületekre, illetve a városkörnyékre fokozatosan kiszoruló szegények is ennek példái (van Criekingen 2003). 
Ettől eltérő modellt képviselnek azok a nyugat-európai (köztük francia) elővárosok, de az észak-amerikai vagy éppen kanadai elővárosok is, amelyek az előbb bemutatottakhoz képest - társadalmi sajátosságaiknak megfelelően más utat jártak be, amelyek a különböző lakáspolitikai támogatások eredményeként jöttek létre a családi életformára koncentráló középosztálybeli, sok esetben felső-középosztálybeli lakosság számára (Jaumain, Lemarchand 2008). Ezt a modellt Európában a felsőbb és az alsóbb társadalmi osztályok térbeli elkülönülése váltotta ki. A párizsi régió esetében például egyértelmű ez a trend, mert amíg a szuburbán övezet nyugati szélén a magas jövedelmű, vezetői rétegek lakta települések (enclave-ek) koncentrációit látni, addig a délkeleti övezetben az alacsonyabb státusúak által benépesített településegyütteseket lehet megtalálni (Cattan, Huet 2011, 13.). Amerikában a jelzett modellt etnikai tartalmak is formálják, egyrészről a fehér felsőosztálybeliek és felső-középosztálybeliek által lakott elővárosok, az amerikai „mainstream”, másrészről pedig az úgynevezett „mások”, a problematikus, gyakran sötét bőrü amerikaiak által lakott alacsony társadalmi státusú (többnyire belső) városrészek ellentmondásai miatt (Williamson, Imbroscio, Alperovitz 2005, 318.).

A kanadai elővárosok az 1950-es, 1960-as években jöttek létre a nagyvárosi terjeszkedés követelményeinek, a városcentrumok válságának, funkcionális átalakulásainak, a középosztály szuburbanizációs, azon belül elkülönülési törekvéseinek, a gépkocsiforgalomra építő életformának is engedve (Harter 2008). Az első időszakban foként fiatal, gyerekes családok érkeztek, az akkor általában 25 éves fiatalok, a baby-boom képviselői, olyanok, akik többnyire 1970-ben léptek a lakáspiacra (Gill, 2008), s akik már nem akartak a szüleik mellett élni. Körükben az egyéni családi ház iránti vágy a felnőtté válás igényével is párosult.

A 2000-es évek első fele azonban jelentős változásokat hozott. 2006-ban a baby-boom képviselői - jellemzően diplomások, magas jövedelműek - már a 60 évesek korosztályának a tagjai. Gyermekeik időközben elköltöztek, visszaköltöztek a városcentrumokba, a belvárosok megújulásának is köszönhetően. Ez gyökeresen átalakította az elővárosokban élő háztartások szerkezetét: jelentősen csökkent a gyerekeikkel együtt élő családok aránya, viszont megnőtt az egyszemélyes vagy egyszülős háztartásoké (a válások következtében is).

A kanadai kutatók szerint az 1990-es évektől kezdve jellemzővé vált idősödés és az individualizáció jelenségei miatt ma már az a kérdés, hogyan lesznek fenntarthatók az elővárosok, amelyek fóként a magas jövedelmü és magasabban képzett középosztálybeliek családos életformája számára létesültek. Az újonnan érkező fiatal családok már alacsonyabb jövedelműek, kevésbé tudnak élni az elővárosi lakáspiac kínálatával, a magasabb jövedelműek ismételt kiáramlására pedig már nem lehet számítani. Például a Montréal nagyvárosi régióban a 25 és 54 év közötti egyedül élő aktív diplomások, főként nők kétharmada a városi létformát választja, a városban lakik, a városi környezet jobban megfelel a mai életformájának (Gill 2008, 61.). 
A kanadai példa a fejlett nyugati országok nagyvárosainak egyre dinamikusabb dzsentrifikciójára, a belvárosi negyedek reneszánszára, ismét megnövekedett társadalmi jelentőségére utal. ${ }^{12}$ A különböző kutatások szerint a belső részekben élő fiatalabb, aktívabb, képzettebb rétegek már a városokban maradnak, sőt a szuburbanizációban kiáramlott középosztály visszaköltözése is érzékelhető folyamat. Ez hosszú ideje európai jelenség is. Az utóbbi tíz évben Párizs esetében is megfigyelhető a visszaköltözés, ennek köszönhetően a város lakossága 3\%-kal, a belső negyedeké pedig 6\%-kal növekedett (Cattan, Huet 2011, 5.). Mindez az elővárosi környezet jövőbeli új társadalmi tartalmát is sejteti: a középosztálybeliek által lakott szuburbiák jelentőségének (esetleg arányának) visszaesését, az alacsonyabb társadalmi státusúak által benépesített városkörnyék lélekszámának növekedését. Hiszen a középosztálybeliek elővárosi életforma iránti vágya enyhülni látszik, miközben a városkörnyék új társadalmi rétegek számára is vonzóvá és elérhetővé válik.

A nagyvárosi ingatlanárak alakulása részben kifejezi, részben erősíti a folyamatot. Az utóbbi tíz évben a párizsi belső kerületek ingatlanárai drasztikus módon megnövekedtek, a 2000-es évi árak háromszorosára emelkedtek. Ma már átlagosan 7 ezer euró egy négyzetméter lakás ára az úgynevezett „Beaux Quartiers"-ben, vagyis a valóban jó negyedekben (Bronner 2010, 9.). Ez a meglévő térbeli társadalmi hierarchiát erősíti fel, a középosztálybeliek nagyvárosi kötödését, az alacsonyabb (nem csak az iskolázatlan, hanem inkább az alacsonyabb jövedelmü) társadalmi státusú csoportok, köztük a pályakezdő fiatalok, alsó középosztálybeli családok dinamizálódó kiköltözését, vagy a szegényebbeket érintő, felgyorsuló kirekesztés folyamatait.

A párizsi belső részekről már ténylegesen vagy csak potenciálisan kiszorulókért szinte harc indult meg a régió külső negyedei részéről. Az elővárosok geográfiai, illetve társadalmi pozícióik szerint várják és hívják a fiatal, aktív, alsó-középosztálybeli családokat vagy kisebb jövedelmü középosztálybelieket. A társadalmi szerkezetüket javítani óhajtó elővárosok kritikusan bírálják azt a 2007-es törvényt, amely az érzékeny városi zónákban élők lakásproblémáit akarja mindenekelőtt kezelni, a lakásfelújítások támogatási rendszerén keresztül. Ez a törvény a bírálók szerint a gettósodás veszélyét növeli, mivel akadályozza a társadalmi heterogenitás erősödését, ami ellentmond az elővárosi rehabilitációt támogató beavatkozásoknak, az erre fordított források hatékonyságának, jóllehet az utóbbi támogatás kiemelt célja a homogén, hátrányos helyzetű népesség által lakott elővárosok társadalmi megújulása. $\mathrm{Az}$ érvek mögött kimondva vagy kimondatlanul érezni lehet a társadalmi kirekesztési törekvéseket, a ma stigmatizált vagy a megbélyegzettség határán álló elővárosok presztízsnövelésének célját az új és magasabb státusú lakók vonzása révén.

Egyetértve a francia szociológusok nézetével kijelenthető, hogy a szegény elővárosi negyedek problémáit nem lehet a biztonság fokozásával, a bevándoroltak kulturális eltéréseire adott válaszokkal (több rendőrrel, jobb 
oktatási rendszerrel) enyhíteni (Le Goaziou, Rojzman 2006, 122.). A térbeli társadalmi problémák továbbgörgetése nem ad gyógyírt, hiszen a feszültség áthelyezéséről és nem megoldásáról van szó. Ennek sokkal szélesebb körünek, strukturálisnak kell lennie.

\section{Város és környék dichotómiája a magyar nagyvárosi térségekben}

Egy 2005-ben végzett reprezentatív vizsgálat feltárta a 9 hazai nagyvárosi térség, köztük a budapesti várostérség térbeli társadalmi szerkezetét, a centrumtérség belső egyenlőtlenségeit, kimutatta a városok és a környékek, illetve a környékek közötti társadalmi dichotómiákat (Szirmai 2009a). ${ }^{13}$ Az adatok rámutattak, hogy a városokban, azok centrumrészein erőteljesebb a magasabb társadalmi státusúak (magasabban iskolázottak, magasabb beosztásúak, nagyobb jövedelmüek) jelenléte, míg a város külső negyedeiben és a városkörnyékeken az alacsonyabb társadalmi státusúak (alacsonyabban iskolázottak, alacsonyabb beosztásúak, kisebb jövedelmüek) aránya a jellemzőbb. (Ennek az iskolázottsággal kapcsolatos példáját lásd az 1. és a 2. ábrákon.) Fontos trend, hogy a városcentrumból a városkörnyékek felé haladva a térbeli társadalmi szerkezet egyértelműen hierarchikusan alakult. A városok és térségeik gazdasági, infrastrukturális és intézményellátottságát is kifejező ökológiai térbeli

1. ábra: A 9 magyar nagyvárostérség különböző övezeteiben élők iskolai végzettség szerinti megoszlása, 2005

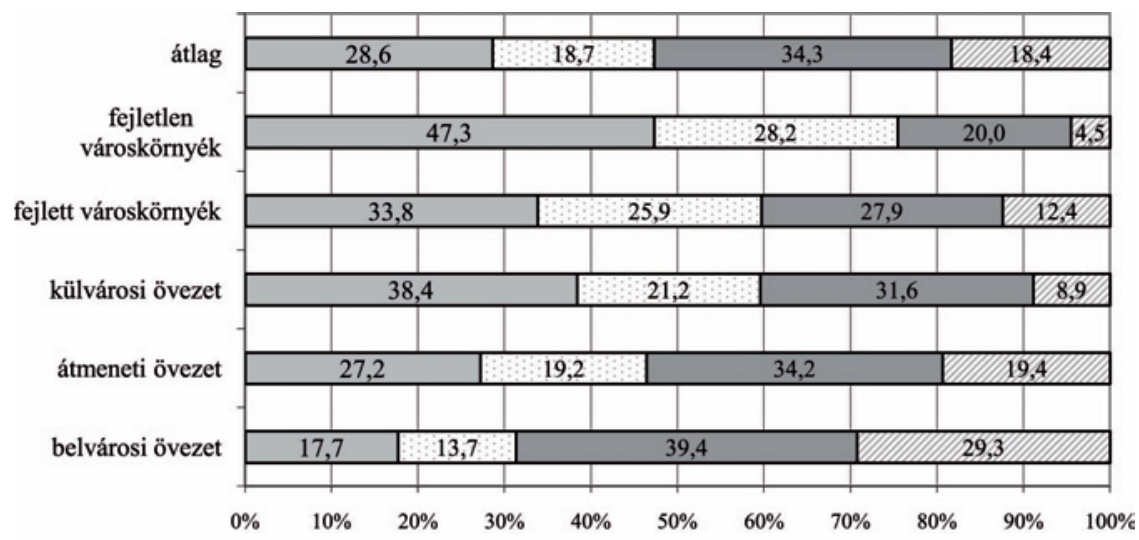

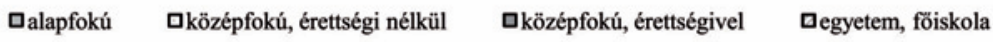

Forrás: NKFP-kérdőív adatai. 
2. ábra: A budapesti várostérség különböző övezeteiben élők iskolai végzettség szerinti megoszlása, 2005

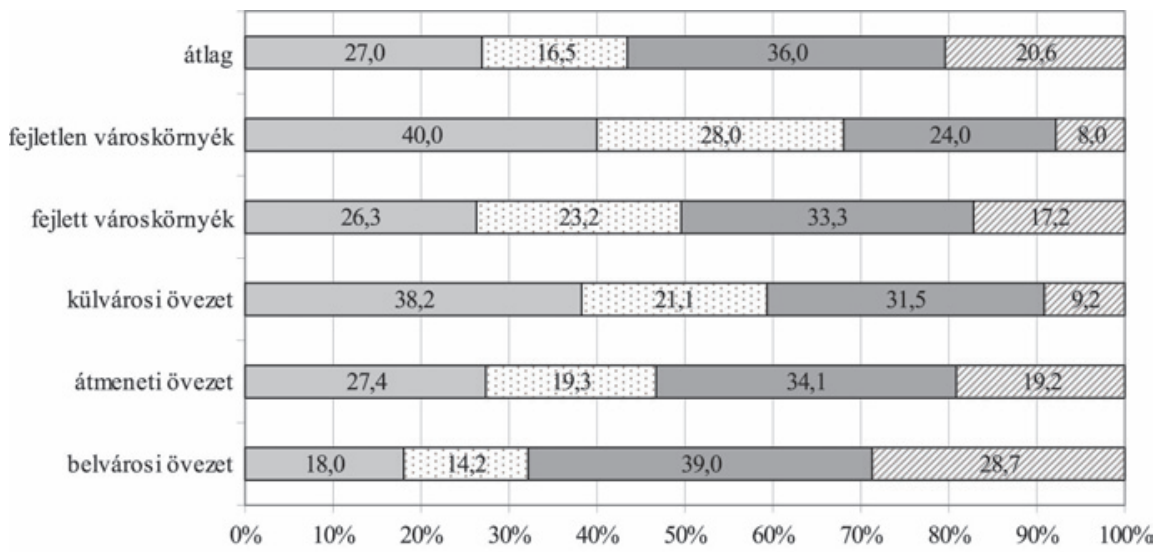

$\square$ alapfokú $\square$ középfokú, érettségi nélkül $\square$ középfokú, érettségivel $\square$ egyetem, föiskola

Forrás: NKFP-kérdőív adatai.

lejtőn - a centrumtól fokozatosan távolodva - egyrészt csökken a magasabb státusúak, másrészt növekszik az alacsony státusúak aránya. Ezt a hierarchiát azonban a kedvezőbb földrajzi helyzetben lévő, jobb infrastruktúrával rendelkező, fejlettebb városkörnyéki településeken élő magasabb társadalmi státusúak nagyobb arányai megtörték. (Ezt a jelenséget neveztem kettős térbeli társadalmi hierarchiának, a centrum és a periféria átalakult rendszerének (Szirmai 2009b)).

A 2010-es budapesti várostérségi vizsgálat megalapozásakor kiemelt cél volt az összehasonlíthatóság. ${ }^{14} \mathrm{Az}$ elemzések alapján 2005 és 2010 között fontos változások érzékelhetők a népesség területi elhelyezkedésében. ${ }^{15} \mathrm{Az}$ iskolai végzettség, a munkahelyi beosztás és a jövedelem szerinti összevetések alapján egyrészt a térségi hierarchia átrendeződni látszik, másrészt a lényeges különbségek a városcentrum és a környék, illetve a városcentrum és a fejletlen városkörnyék közötti eltérésekben jelennek meg.

A város belső övezetei között 2005-ben érzékelhető erőteljes hierarchikus elrendeződés enyhült, 2010-ben az iskolai végzettség, a munkahelyi beosztás és a jövedelem szempontjából viszonylag kiegyenlítettebbek a városövezeti megoszlások, a magasabb társadalmi státusúak korábban inkább belvárosi koncentrációja most visszafogottabb, elhelyezkedése a fóváros egyéb belső negyedeire is kiterjedő. Jelentős különbség azonban, hogy míg a 2005-ös vizsgálatban a magasabb státusúaknak csak a belvárosi koncentrációja lépte túl a mintabeli arányokat, addig 2010-ben a városi arányai a magasabbak. A jövedelem szerinti megoszlások ettől eltérőek. Amíg 2005-ben a 
legmagasabb jövedelműek a mintaátlaghoz képest nagyobb mértékben a belvárosban jelentek meg, addig 2010-ben a mintához képest magasabb arányokban a fejlett agglomerációs településeken találjuk meg őket.

$\mathrm{Az}$ alacsonyabb társadalmi státusúaknak a belvárostól a külsőbb negyedek felé hierarchikusan növekvő arányai esetében is relatív kiegyenlítődés tapasztalható. 2005-höz képest jelentős különbség, hogy amíg 2005-ben az alacsony státusúak városi arányai a mintabeli átlaghoz képest magasabbak voltak, ezek az arányok 2010-ben alacsonyabbak, miközben a fejletlen városkörnyéken magasabbak (lásd a 3., 4., 5., és 6. ábrákat).

A budapesti várostérségre vonatkozó 2010-es eredmények, valamint a 2005ös és a 2010-es kutatási tapasztalatok összehasonlítása alapján egyrészt erősödni látszik a magas társadalmi státusúak városi (már nemcsak belvárosi), illetve a fejlett városkörnyéki településekre érvényes koncentrációja. Másrészt jellemzőbbé válik az alacsony társadalmi státusú csoportoknak főként a fejletlenebb városkörnyéki településeken történő elhelyezkedése. Mindez a város és a környék társadalmi szerkezetének dichotómikus elrendeződését mutatja, továbbá azt a feltevést is sugallja, hogy a Budapest térségben élők területi elhelyezkedésének rendje fokozatosan követi a nyugat-európai modellek példáit, az ottani fó folyamatokat. ${ }^{16}$ Ezt a hipotézist a Norway Grants kutatási program keretében most elkészült, a francia, az osztrák és a dán fővárosra, valamint térségeikre kiterjedő, az „urban sprawl" folyamatát feltáró tanulmányok eredményei is igazolni látszanak (Cattan, Huet 2011, Reeh, Zerlag 2011, Görgl et al. 2011). ${ }^{17}$

3. ábra: A budapesti várostérség különböző övezeteiben élők munkahelyi beosztás szerinti megoszlása, 2005

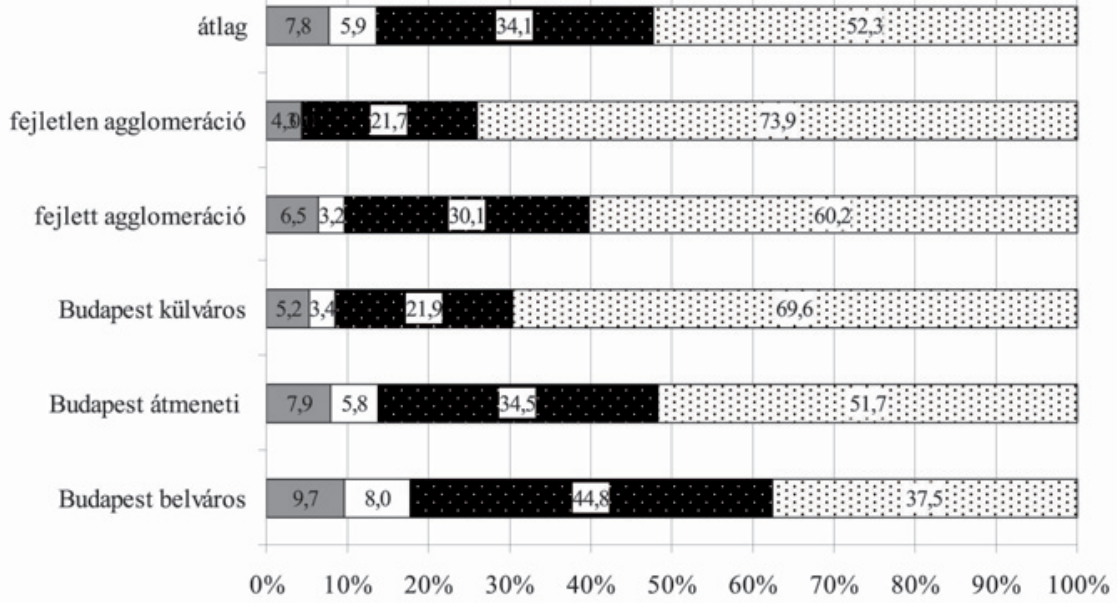

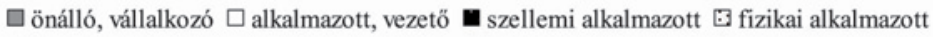

Forrás: NKFP-kérdőív adatai. 
4. ábra: A budapesti várostérség különböző övezeteiben élők munkahelyi beosztás szerinti megoszlása, 2010

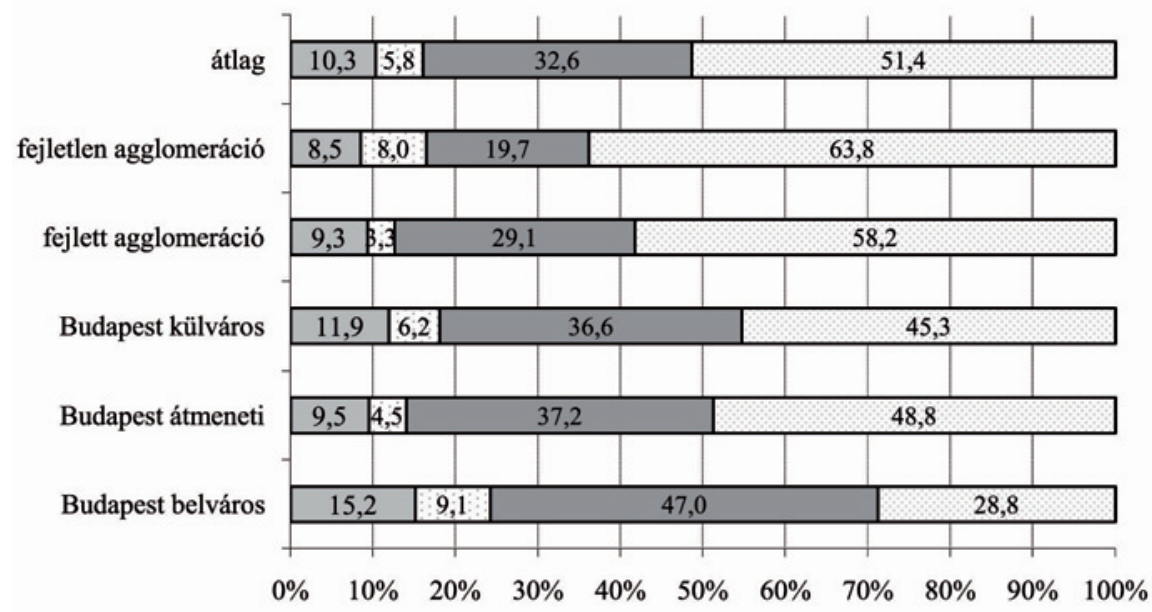

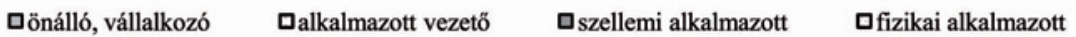

Forrás: Norway Grants kérdőív adatai.

5. ábra: A budapesti várostérség különböző övezeteiben élök havi nettó jövedelem szerinti megoszlása, 2005

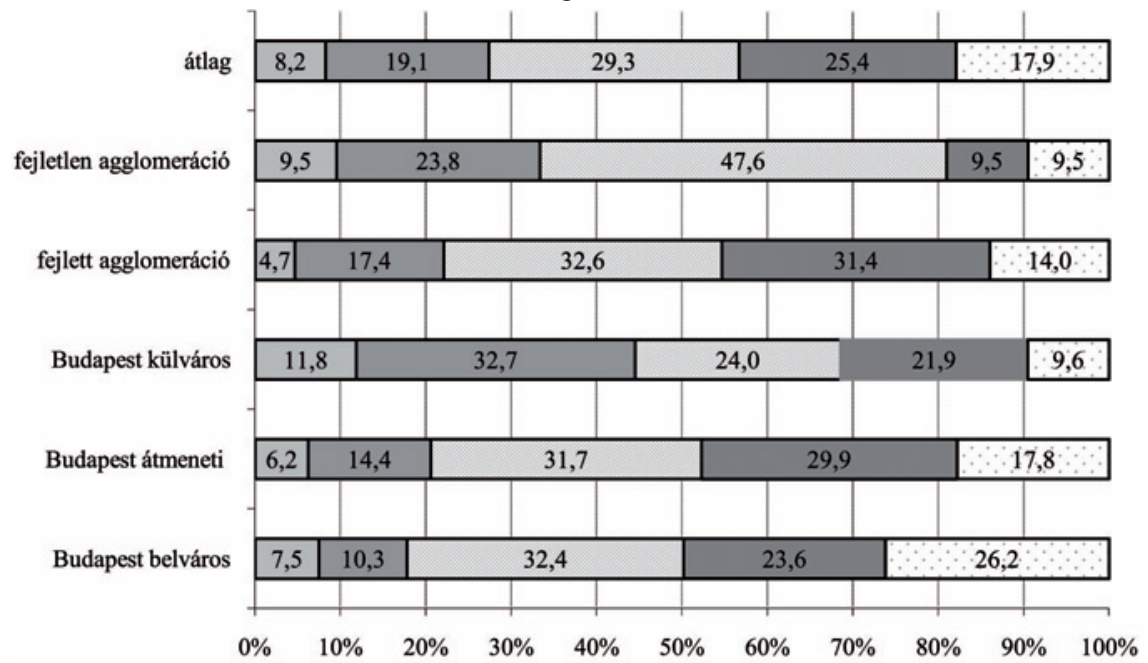

口nincs jövedelme

प50 ezer forintnál kisebb

口50-75 ezer $\mathrm{Ft}$

口76-100 ezer Ft

ه100 ezer forintnál több

Forrás: NKFP-kérdőív adatai. 
6. ábra: A budapesti várostérség különböző övezeteiben élök havi nettó jövedelem szerinti megoszlása, 2010

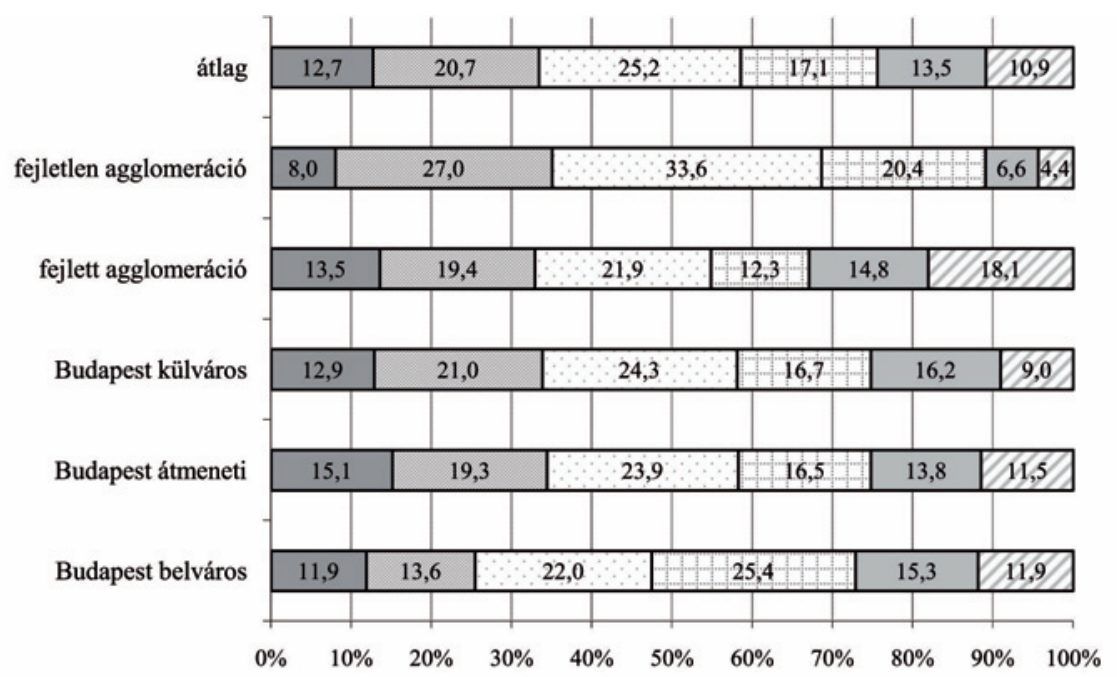

$\square 50$ ezer Ft alatt $\square 51-75$ ezer Ft $\square 76$-100 ezer Ft $\square 101-125$ ezer Ft $\square 125-150$ ezer Ft $\square 150$ ezer Ft felett

Forrás: Norway Grants kérdőiv adatai.

\section{Város és környék kapcsolatrendszerei}

Az államszocialista redisztributív (újraelosztási) rendszerben a helyi hatalmak, a települések nagyon szűk tervezési és fejlesztési mozgástérrel rendelkeztek. Hiányoztak az önállóságot biztosítani képes törvényi feltételek és lehetőségek. Ezért az 1990-ben lezajlott társadalmi, politikai változások felerősítették a városkörnyéki önkormányzatok önállósodási törekvéseit, aminek jogi feltételeit az új önkormányzati törvény biztosította, jóllehet a különböző fejlesztésekhez szükséges források biztosítása többnyire elmaradt. Mindez nem volt összhangban sem a törvény adta elvi önállósodási lehetőségekkel, sem az átmenet követelményeivel.

A globális gazdasági hatások, valamint az, hogy a külföldi nagyvállalatok a városkörnyéket is szívesen választották beruházásaik, fejlesztéseik területeként, oldani kezdték a centrumok és a környékek között történetileg kialakult gazdasági egyenlőtlenségeket. Különösen lényegesek voltak az 1990-es évek elején a (főváros után) elsőként a budapesti agglomerációban, majd a többi nagyvárosban és térségeikben felépített, többnyire zöldmezős városkörnyéki bevásárlóközpontok. A városkörnyékeken újonnan létesült vállalkozások is hozzájárultak a centrumtérségek gazdasági előnyeinek enyhüléséhez. 
A városkörnyéki gazdasági potenciál növekedése, illetve az állami fejlesztési források nem kielégítő mértéke közötti ellentmondások részben konfliktusokat generáltak, részben tovább ösztönözték a helyi önállósodási törekvéseket, főként a fejlettebb városkörnyékek esetében. Ezeket a törekvéseket a rendszerváltozás során felerősödő, a középosztálybeliek által megvalósított szuburbanizációs folyamatok is táplálták. A belvárosi problémák, a hiányzó városfelújítás, de az új lakáspiaci lehetőségek, a vidéki ház iránti igények is gyorsították a kiköltözés folyamatát. ${ }^{18} \mathrm{~A}$ polgárosodás, a jólét erősödése mellett a zöldértékek is hozzájárultak a vidéki természeti környezet iránti vágyak növekedéséhez. Hasonló hatásokkal jártak a fogyasztói társadalom értékei is. Az 1990-es években felfutott és egyben megújult gépjármüpark, a rá alapozott (törekvéseiben amerikainak mondható) életforma iránti vágyak szintén a kiköltözést dinamizálták.

A városkörnyéki települések hosszú ideig nyitottak voltak a szuburbanizációra. A külső települések kerestek és találtak is eszközöket arra, hogy új otthont kínáljanak. Településenként eltérő mértékben ugyan, de alapvetően mindegyik növelni óhajtotta a lakosságszámot, minthogy ettől (is) növekvő bevételeket remélt. Ennek a célnak rendelte alá telekpolitikáját, fejlesztési céljait.

Az eredmény nemcsak az volt, hogy a városkörnyék új adófizető polgárokhoz jutott, hanem az is, hogy az 1990-es évek során a városkörnyéki lakóhelyi infrastruktúra jelentős mértékben fejlődött, a lakáskörülmények javultak. Az új elővárosi lakók sok esetben vállalkozásokba is fogtak, vagy a helyi foglalkoztatási lehetőségekkel éltek, s ezzel a települési önkormányzatok helyi forrásai bővültek.

A főváros és a környékbeli települések között mindig ellentmondás volt a szuburbanizáció megítélésében. A fóváros illetékesei (és meghatározott szakmacsoportok is) ellenezték az 1990-es években fokozatosan felgyorsuló kiáramlást, aminek a személyi jövedelemadó helyben maradó részének területi megosztása volt az oka, továbbá a nagyvárosi népesség egyre erőteljesebb csökkenése miatti aggodalom is.

A városkörnyéki gazdaság fejlődését akadályozó különböző tényezők miatt, valamint a személyi jövedelemadó helyben maradó részének fokozatos elvonása következtében a városkörnyéken is megjelentek a szuburbanizációval kapcsolatos ellenérzések. A helyi önkormányzatok számára is egyre nyilvánvalóbbá vált, hogy nem képesek biztosítani a megnövekedett népesség számára szükséges infrastruktúrát, nem tudják kielégíteni sem a régiek, sem az újonnan érkezettek gyermekintézményekre, egészségügyi szolgáltatásokra vonatkozó igényeit. A Budapest környékbeli települések önkormányzatai közül többen is úgy vélik, hogy túlzott mértékủ a beköltözés, erőteljesebb, mint ahogy remélték, ezért már nem kívánatos a népességszámot növelni. ${ }^{19}$

A lakosság körében szaporodik azok száma, akik ellenérdekeltek a növekedéssel szemben, és akik számára a fő cél azoknak az értékeknek a megóvá- 
sa, amelyek miatt valamikor ideköltöztek, ez pedig a csend, az elszigeteltség, a nyugalom. S bár a városterjeszkedéssel szemben álló „urban sprawl” ellenes mozgalmakról ${ }^{20}$ nem beszélhetünk, szinte minden vizsgált településen létrejönnek a népességszám növelését ellenző helyi konfliktusok.

$\mathrm{Az}$ új ingatlanfejlesztések is számos helyi összeütközést generálnak. A részt vevő társadalmi szereplők általában ugyanazok. Az elszigeteltségben, vagy a meglévő körülmények megőrzésében többnyire az őslakosság érdekelt, de azok az újabbak is, akik már integrálódtak a településbe, akik már nem örülnek a még újabban érkezőknek, hiszen úgy érzik, hogy azok kiszorítják őket a lakóhelyi intézményekből, a munkahelyekről is, megzavarják a kialakult elővárosi életformát. Ezt néha azokkal kapcsolatban is megfogalmazzák, akik más településeken laknak, de a vizsgált lakóhelyek infrastruktúráját használják. Az igazi őslakosság és az újak között is vannak életformabeli ellentmondások. Az előbbiek joggal érzik úgy, hogy az utóbbiak elutasítják a meglévő életforma őket zavaró elemeit, hiszen míg a régiek számára az előváros nemcsak lakó-, hanem munkahely is, a ház környéke és kertje a termelés helye, a most érkezettek fóként lakóhelyet kerestek, és ahhoz a csendet, nyugalmat várják el.

A népességet növelni törekvő korábbi helyi önkormányzati elképzelések helyett (elsősorban a személyi jövedelemadó helyben maradó részének jelentős csökkenése és a helyi iparüzési adó számottevő bővülése miatt) ma már inkább a gazdaság dinamizálása a fö törekvés, 2000 óta ennek rendelik alá a

7. ábra: A lakóterületi, gazdasági és egyéb célra múvelésből kivont területek nagysága a budapesti agglomerációban, 1996-2008

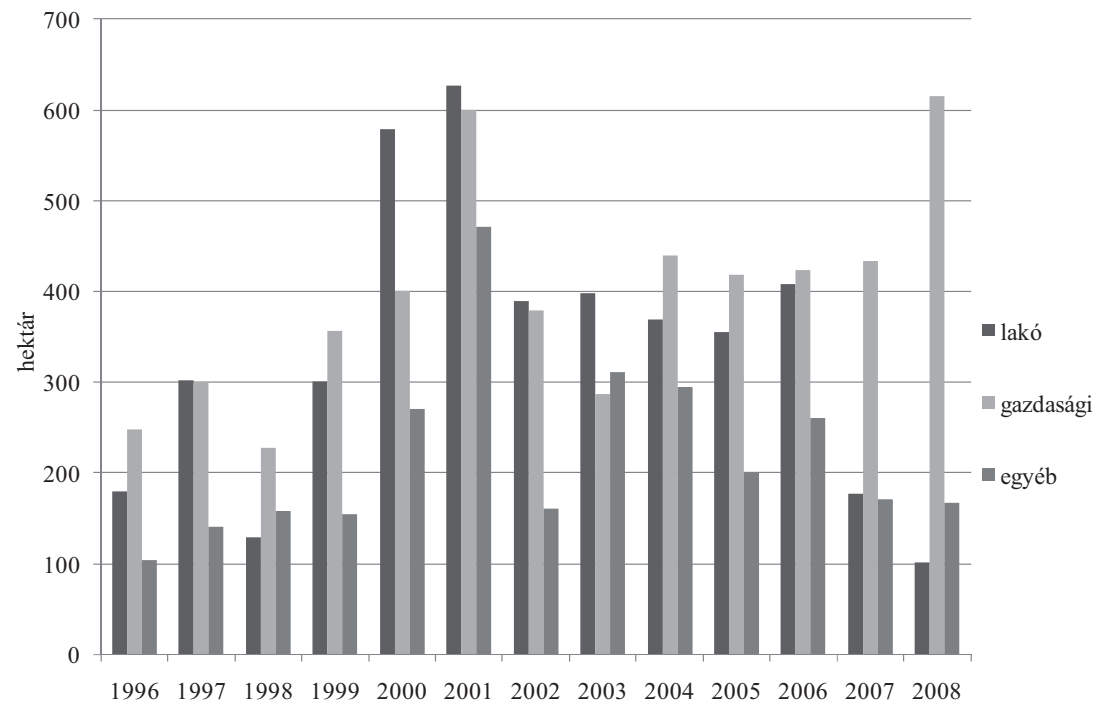

Forrás: PESTTERV Kft. (2010): A budapesti agglomeráció területrendezési tervéról szóló 2005. évi LXIV. törvény módosításának tervezete 
telekpolitikát, a fejlesztési célokat is. A PESTTERV Pest megyei Terület, Település-, Környezet Tervező és Tanácsadó Kft. elemzései jól mutatják, hogyan változott 1996 és 2008 között a különböző célú művelésből kivont területek nagysága, az évek alatt hogyan csökkentek a lakóterületi és hogyan növekedtek a gazdasági (kereskedelmi) területi fejlesztések (lásd a 7. ábrát).

A városkörnyéki gazdasági (közte kereskedelmi) fejlesztések sem mentesek a város és a környék közötti konfliktusoktól. Hiszen a különböző típusú vállalkozások (köztük a multi vagy transznacionális cégek magyar telephelyei) megszerzéséért vagy a bevásárlóközpontok területi elhelyezkedéséért is komoly verseny folyt. S minthogy ebben a versenyben a főváros korábbi és mai előnyei nemcsak nyilvánvalóak, hanem a tények szerint az érdekeltek nem is akarják a lehetséges előnyöket a többi környékbeli településsel megosztani (azért sem, mert kevés a felosztható előny), a környékbeli települések közül többen bezártságra kezdenek törekedni, kimondatlanul, de egyre inkább kimondva is. A ma jellemző versenyszellem, a minden szinten érzékelhető forráshiány is azt sugallja, hogy az individuális részvétel hatékonyabb, mint a közösségi.

\section{A városi terjeszkedés jövője}

Nyilvánvaló, hogy a városi terjeszkedés jövője nemcsak a lakosság költözési törekvéseitől, hanem a gazdaság igényeitől, a demográfiai folyamatoktól, az érintett népesség életkilátásainak alakulásától, az országos regionális egyenlőtlenségekből adódó területi mozgásoktól is függ. De a költözési törekvések szerepe sem elhanyagolható, emiatt ezek vizsgálatára is vállalkoztunk. Már a 9 nagyvárostérséget elemző kutatásból is kiderült, hogy a nagyvárosi népesség jelentős része (közel $80 \%$-a) nem akar elköltözni, a városlakók csupán 13\%-a mondta, hogy biztosan el fog költözni, 7,3\%-a pedig azt válaszolta, hogy elköltözne, de nincs rá lehetősége. A városkörnyékieknek csupán 4,5\%-a állította, hogy költözni fog, további 4,5\%-a azt mondta, hogy megtenné, de nincs rá módja (Szirmai 2009c, 54.). A budapesti várostérség esetében hasonló volt a 2005-ös trend, 79,4\% nem akart, 13\% pedig akart költözni, 7,1\% a költözési szándékot, de inkább annak akadályait említette.

A 2010-es Budapest-térségi vizsgálat meglepő eredménye volt a korábban is alacsony költözési szándék 10,1\%-ra történő csökkenése. Továbbá az is, hogy 3,3\%-ra esett vissza azok aránya, akik elmennének, de nincs rá lehetőségük. Ennek egyik tényszerü oka a mai gazdasági válság, a lakás- és hiteltartozások költözést visszafogó következménye, különösképpen a fejletlen városkörnyéki településeken élő, hátrányosabb helyzetü, alacsonyabban iskolázott rétegek esetében.

A kiköltözést visszafogó tényező volt az is, hogy 2003 és 2006 között 
Budapesten 35 ezer új lakás épült. Ebből lakóparki formában több mint 6 ezer új lakás készült el (Cséfalvay 2008, 23.). Valószínü, hogy a fővárosban épített új lakóparkok „felszívták” azokat, akik elégedetlenek voltak a többnyire belső kerületi vagy éppen lakótelepi lakásaikkal, és akik tiszta és biztonságos, másképp fogalmazva olyan szuburbán környezetbe vágytak, amely egy időben nyújtotta a városi és szuburbán élet előnyeit. ${ }^{21} \mathrm{Ez}$ a döntésük megóvta őket a bejárás nehézségeitől, az elővárosi viszonyok kialakulatlanságától is.

A hitelproblémák inkább az alacsonyabb társadalmi státusú csoportok, a lakóparkfejlesztések pedig inkább a magasabb társadalmi státusúak esetében eredményezik a városcentrumból történő költözési törekvések visszaesését. Nyilván nem kizárólag ezért, de emiatt is 2007 óta csökkent a fővárosi kiköltözés dinamikája, sőt enyhe népességnövekedés is látszik. ${ }^{22}$

A fővárost és környékét összekötő közlekedési utak állapota, a megnövekedett gépkocsiforgalom miatti zsúfoltság, az állandósult dugók, a városfejlődés dinamikájától jóval elmaradt mennyiségi és minőségi tömegközlekedés mind-mind szerepet kapnak akár a költözési célok visszaesésében, akár a visszaköltözési igényekben.

Mindez arra utal, hogy a közeljövőben valószínűleg nem várható a lakossági kiköltözéssel összefüggő drasztikus városi terjeszkedés. Adataink szerint a költözést tervezők, főként belső városnegyedek magasabb társadalmi státusú csoportjainak a nagy része (közel 69\%-a) Budapesten akar maradni, közel 19\% azok aránya, akik az agglomerációt választják, 6,5\% pedig egyéb települések mellett dönt. Mindez tovább erősíti a centrum és a környék közötti, korábban már igazolt társadalmi dichotómia szerveződését, a magasabb társadalmi státusú csoportoknak részben centrumbeli, részben a fejlettebb városkörnyéken tapasztalható koncentrációit, egyszersmind a centrum és a fejlett városkörnyék közötti társadalmi hasonlóságokat, illetve a centrum és a fejletlen környék közötti eltéréseket.

\section{Összegzés}

A városi terjeszkedés mai folyamatai a kompakt vagy szétszórt város dichotómiája helyett új struktúrákat eredményezett, eltérő társadalmi tartalmú térbeli-társadalmi dichotómiák modelljeit, azok mai változásait. A budapesti régió kutatási eredményei alapján ma erőteljesnek látszanak a város és a környék közötti ellentmondások, ezeknek több szimptómája is érzékelhető. A régió társadalmi szerkezete hierarchikus, egyenlőtlen. A városkörnyéken is létrejöttek a magasabb és az alacsonyabb ökológiai és társadalmi pozíciójú települések. S bár az eltérések nem adják a nyugati típusú felsőosztálybeli és középosztálybeli, illetve a társadalmilag érzékenyebb, alacsony státusú települések 
és a centrumok erőteljes dichotómiáját, de már érzékelhetők a dichotómiákat szervező folyamatok. A fejlett városkörnyéki települések lakóinak magasabb a jövedelme, jobb az iskolázottsága (valamivel idősebbek, inkább házasok). ${ }^{23} \mathrm{~A}$ fejletlenebb városkörnyéki településeken élők alacsonyabban iskolázottak, alacsonyabb, illetve közepes a jövedelmük (fiatalabbak, inkább ott vannak a munkaerőpiacon is). ${ }^{24} \mathrm{~A}$ települési (tehát a centrum- és a környékbeli) önkormányzatok között történetileg változóak a kapcsolatok; a mai viszonyok és érdekeltségek, kulturális tényezők inkább a zártságra ösztönöznek.

Mindez azt is igazolja, hogy az urbanizáció történeti útjait nem lehet megkerülni, a fejletlenebb országok végül is követik az előbbre járók által már kijelölt vagy bejárt utat, az urbanizáció főbb törvényszerüségeinek érvényesülései miatt. Ezek a törvényszerüségek néha arra is képesek, hogy felülírják a tudatos terület- és településfejlesztési beavatkozások céljait és hatásait. Ez utóbbi szempont nélkül aligha lennének könnyen magyarázhatók az európai és a magyar városkörnyéki társadalmi hasonlóságok, a magas és az alacsony társadalmi státusú települési dichotómiák, amelyek eltérő társadalmi és történeti kontextusban, differenciált gazdasági fejlettség közepette, a folyamatok alakításában részt vevő szereplők különböző aktivitásai alapján jöttek létre. De ennek a kérdésnek a feltárása már egy másik kutatás tárgya.

\section{Jegyzetek}

1 Az Amerikai Egyesült Államokban az 1930-as években kidolgozott New Deal, a kormányzat új gazdaság-, társadalom-, valamint hitelpolitikája indította meg az elővárosi fejlődést, amelyet az 1950-es évek lakásépítési támogatásai, a hosszú lejáratú, 20-25 évre szóló hitelek tovább dinamizáltak (Batár 1999). Az új amerikai életideált hirdető, szuburbán életforma marketingje is hatást gyakorolt a folyamatokra, hiszen választ kínált a nagyvárosi léttől elfáradt akkori középosztálybeliek igényeire, egy új életstílus, a kevesebb zaj, a kisebb forgalom, a kevesebb bűnözés, sőt a szegényektől való védettség, a lokális közösségi kohézió megteremtésének az ígéreteivel (Williamson, Imbroscio, Alperovitz 2005).

2 A rendelkezésünkre álló terjedelem sajnos nem teszi lehetővé, hogy adatokkal is illusztráljuk az amerikai, illetve az európai nagyvárosi folyamatot. Az adatokat lásd: http://www.census.gov/population/www/documentation/twps0027/twps0027.html\#tabA

Table B. Population of the 20 Largest Cities and Urbanized Areas: 1990

3 A dán fóváros esetében az 1945-ös „Fingerplan” szerepére kell utalni, amely a jóléti állam tervezési eszközeként, tudatosan fejlesztette és egyben irányította a Koppenhága nagyrégió fejlődését, a szuburbanizációt, az akkori középosztálybeliek kiköltözését, bérbe vehető családi házak építésével, a szükséges közlekedési és egyéb infrastruktúra megteremtésével. A terv a mai folyamatokra is hatással van, bár a városkörnyék ma az állam által támogatott banki hitelstruktúrák segítségével, az állam és az önkormányzat, valamint a privát területfejlesztők, a befektetők együttműködésével alakul (Reeh, Zerlag 2011).

4 A párizsi régió esetében is tudatos cél volt a fejlődési folyamatok irányítása, amelyben az állam kiemelkedő szerepet játszott, főként az 1960-as, 1970-es években. Ezek között kiemelkedő az új városfejlesztési program, amely az új városok helykijelölésével határozta meg a peri-urbaine fejlődés fő irányait, egyszersmind a (lakótelepekkel elégedetlen) középosztálybeliek városkörnyéki elhelyezkedésének fő célterületeit is (Szirmai 1988). A városkörnyéki 
területek mai alakulását már főként a piaci erők szabályozzák, a banki hitelstruktúrák segítségével, a társadalmi igények és lakóhelyi szükségletek szerint. Az utóbbi esetben a párizsi igen magas ingatlanárak szerepe kiemelkedően fontos, a városi lakosság egyre nagyobb arányban törekszik városkörnyéki olcsóbb ingatlanhoz jutni (Cattan, Huet 2011).

Az 1990-es években lezajlott budapesti városkörnyéki növekedés esetében alapvetően ellentmondásos hatásokat találni: részben a főváros védelmét, részben a környék fejlődését ha nem is támogató, de engedő folyamatokat. Mindez azt jelenti, hogy az állam és az érintett önkormányzatok átengedték a terepet a piaci erőknek, a városkörnyék fejlődésében érdekelt gazdasági csoportoknak, nemcsak a kiköltözni vágyó középosztálybelieknek, de az alacsonyabb státusúaknak is. Ezt az mutatja, hogy az állami, a regionális, illetve a fóvárosi tervek szintjén megjelentek ugyan a terjeszkedést korlátozó elképzelések (ennek érdekében például a belső városnegyedeket megújítani akaró tervek), miközben a szükséges források, jogi és érdekeltségi eszközök hozzárendelése lényegében elmaradt. Az állami lakás- és hitelpolitikák nem jelöltek ki fejlesztési prioritásokat, így nem befolyásolhatták érdemben a városkörnyéki fejlődést, amelyet a föld és a lakásprivatizáció eredményeként létrejött privát tőke, valamint az új szuburbanizációs költözési igények is mobilizáltak. (A Budapest környéki folyamatok alakulásának a terület- és településfejlesztéssel összefüggő okait egy másik tanulmányban majd részletesen is bemutatjuk.)

6 A városi terjeszkedés fogalmát a nemzetközi szakirodalom többféle értelemben használja. A gazdasági és a társadalmi szuburbanizáció, a városból történő kiköltözés, ezek következtében a városi és városkörnyéki népesség számának és arányának, a várostérségen belüli elhelyezkedésének, a belső népességarányoknak az átalakulása, valamint a területhasználat változásai egyaránt a fogalomhoz tartoznak, mint ahogy a kompakt város felbomlása és a diszperzió is. A térbeli társadalmi szerkezetre gyakorolt hatások szintén fontos indikátorok, ahogy a tervezési beavatkozások hiánya vagy éppen célzott jellege is.

7 A projekt konzorciumi keretben valósult meg, a Nemzeti kutatási fejlesztési programok (NKFP) támogatásával (nyilvántartási szám: 5/083/2004). A konzorcium vezető intézménye az MTA Szociológiai Kutatóintézet, a kutatás vezetője Szirmai Viktória volt. A konzorcium tagjai az MTA Regionális Kutatások Központja Közép-dunántúli Osztálya, a Kodolányi János Főiskola, a PESTTERV Pest Megyei Terület-Település-Környezet Tervező és Tanácsadó Kft., valamint a Székesfehérvári Regionális Vállalkozásfejlesztési Alapítvány voltak. A kutatás mintaterülete a kilenc magyarországi nagyváros: Budapest és agglomerációja, a nyolc 100 ezernél népesebb nagyváros: Debrecen, Győr, Kecskemét, Miskolc, Nyíregyháza, Pécs, Szeged és Székesfehérvár, valamint térségeik voltak. A kutatás számos módszerre épült, a legfontosabbak az 5248 fö megkérdezésén alapuló reprezentatív kérdőíves adatfelvétel és a 108 mélyinterjú, valamint a statisztikai adatbázis-elemzések.

8 A projekt konzorciumi keretben valósult meg, a Budapesti Corvinus Egyetem vezetésével, a Norway Grants (Norwegian Financial Mechanism) támogatásával (referenciaszám: 0056/NA/2006-2/ÖP). Az MTA Szociológiai Kutatóintézet által végzett részkutatást Szirmai Viktória irányította. Az eredményeket a budapesti várostérségekben megvalósított 1000 fóre kiterjedő reprezentatív kérdoíves adatfelvétel és 53 mélyinterjú adja.

9 A tanulmányt megalapozó empirikus adatelemzésekben részt vettek: Baranyai Nóra szociológus-politológus, Kovács Szilvia közgazdász-szociológus, Laki Ildikó szociológus, Schuchmann Júlia geográfus, Váradi Zsuzsanna geográfus.

10 A szóban forgó negyedet most kezdik felújítani.

11 A zónát az elővárosi problémák tervezéspolitikai válaszaként az 1990-es évek derekán jelölte ki a politikai akarat. 1996-os törvény és annak módosítása 751 érzékeny zónát (megközelítőleg 26 ezer városnegyedet) határolt le. Ebből 396 a francia nagyvárosi térségekben található. Az 5 millió ember kb. negyede él a párizsi régióban.

12 Egyetértek azokkal a nézetekkel, amelyek szerint a belváros reneszánsza nagyon differenciált módon zajlik le a különböző országokban. Az eltérések főként az európai és az északamerikai városok között szignifikánsak. Az előbbiek esetében különböző társadalmi csoportok, és nem csak a yuppie rétegek valósítják meg a belső részek felújítását, mint ahogy azt például Manhattan esetében, vagy a Sassen által leírt globális városcentrumokban, New 
Yorkban, Londonban, Tokióban látni (van Criekingen 2003, Sassen 1991), mert a különböző csoportok különböző beavatkozási eszközökkel újítják meg a belső negyedeket, ami differenciált épített környezetet, eltérő fogyasztási lehetőségeket és eltérő társadalmi tartalmat okoz (van Criekingen 2003, 96.).

13 A városi övezetek lehatárolását helyszíni bejárással, várostérségi szakértők javaslatai és térképek alapján végeztük, a 9 várostérségre érvényes egységes (a szakirodalomban elfogadott) szempontrendszer alapján (lásd bővebben Szirmai 2009a). Elsőként tizenöt városrésztípust, majd további tipizálás okán a következő részeket különböztettük meg: A belvárosi övezet: más néven (történelmi) városközpont, a city vagy első munkahelyi övezet, ahol a városközpont jellegadó munkahelyegységei találhatók (közigazgatási szervek, pénz- és hitelintézetek, luxusigényeket kielégítő szaküzletek, oktatási és kulturális intézmények, irodák, stb.), de elsősorban az üzleti és kereskedelmi élet, valamint a szórakoztatóipar létesítményei. Inkább intenzív beépítés és többszintes házak, mint a lakóövezeti funkció jellemzi (nagy nappali és kis éjszakai népesség), bár saját lakossága is van. Az átmeneti övezet: két részből, a belvároshoz közeli ipari üzemek és kereskedelmi egységek zónájából és az azt körülölelő - szintén kettős - lakóövezetből áll. A lakóövezet belső részeire néhány szintes épületek (korábban esetleg bérházak), valamint kis zöldterület jellemző. Az itt élők keveset költenek a lakásfenntartásra, ezért fokozatos lepusztulás figyelhető meg. A lakóövezet külsőbb részein főképp különálló, nagyobb kerttel rendelkező családi házas területek találhatók, de jelen vannak a szállodák és apartmanok is. A külvárosi övezet: más néven előváros, amely a nagyvárossal szoros funkcionális kapcsolatot tart fenn, jól elkülönülve a közvetlen közelében fekszik, esetleg korábban közigazgatásilag is önálló település volt, de ma már a nagyváros beolvadt településrészévé vált. Legfőbb szerepköre a lakófunkció (föként családi házas beépítéssel vagy lakóteleppel, újabban lakóparkkal), lakóinak nagy része a városközpontban dolgozik. Végül a háttértelepüléseket rangszámmódszerrel választottuk ki: a megközelíthetőség, a lakáshelyzet, a köz- és felsőoktatás, az egészségügyi ellátás, a vállalkozói aktivitás, az adózás, a jövedelmek, a foglalkoztatás, a munkanélküliség, a mobilitás, a szociális ellátás szempontjait vettük figyelembe. Az így elkészült mutatók összesítéséből kaptuk meg azt a fejlettségi rangsort, amely alapján a három legfejlettebb (Törökbálint, Százhalombatta, Gödöllő) és a három legfejletlenebb (Tök, Tinnye, Szigethalom) településeket kiválasztottuk.

14 Az ehhez szükséges legfontosabb módszertani megoldás a mintavétel szempontjainak kidolgozása volt. 2005-ben a vizsgálat mintaterülete a 9 magyarországi nagyváros és térsége volt. A mintavételi eljárás a mintába bekerült települések mindegyikének egészét tekintve aránytartó volt, nemre, korcsoportra és iskolai végzettségre nézve reprezentatív (a 2005. évi T-STAR-t, valamint önkormányzati adatokat figyelembe véve). A településeken belüli, valamint a mintába bekerült települések közötti lakosságarányt tekintve viszont nem aránytartó rétegzett valószínűségi mintavételt alkalmaztunk.

A 2010-es budapesti várostérségi vizsgálat mintájának kialakításakor a szempontok megegyeztek a korábbi vizsgálatéval. A fóvároson belüli területek és az ott megkérdezendők száma megegyezett a korábbi kutatáséval, a városkörnyéki almintában az elemszám csökkenése miatt nem 3-3, hanem 2-2 településről vettük a mintát, ezek megegyeztek a korábbi kutatásban kérdezettekkel. (2010-ben fejlett városkörnyéki településekként Törökbálint és Gödöllő, fejletlen településekként pedig Tinnye és Szigethalom kerültek a mintába.) A 2010. évi reprezentatív (kor, nem és iskolai végzettség szerinti) kvóta alapja a 2001. évi népszámlálás adatbázisa volt. Az elemzés során ezt a három változót a 2005-ös adatfelvétel alapján súlyoztuk.

15 Ez a tanulmány a főbb eredményeket közli, a részletes elemzéseket a kutatásból készülő kötet jeleníti majd meg.

16 Ennek részletes tesztelésére európai empirikus kutatási összevetésekre is szükség lenne, továbbá a következő hazai népszámlálás eredményeire is.

17 Ennek eredményeit, a magyar esettanulmánnyal együtt, egy angol nyelvủ kötetben adjuk majd közre.

18 Budapest népessége a 2001-2007 közötti években 81793 fővel (éves átlagban 13632 fővel) csökkent, 2007-ben érte el a mélypontot 1696128 fővel. 2007-2009 között azonban a lakónépesség 
kismértékű növekedése következett be. 2009. január 1-jén a főváros lakónépessége 1712210 fő volt. A városkörnyéki népesség 2007 és 2009 között 35885 fővel (évente 17942 fővel) nőtt.

19 A leírt jelenség annak az ellentmondásnak a következménye, amit a 8-as számú lábjegyzetben jeleztem, vagyis az 1990-es években lezajlott budapesti városkörnyéki növekedéssel kapcsolatos tervezéspolitikai bizonytalanság.

20 Az 1990-es évek végén Amerikában kifejezett „urban sprawl” ellenes városi mozgalmak jöttek létre, számos város és megye vezetése, valamint az ellenérdekelt polgárok léptek fel városhatáraik, a zöld területek védelmében, és szavazták meg az ahhoz szükséges források biztosítását is. Számos állam vásárolta fel a városkörnyéki szabad területeket, a területfejlesztési jogokat, és állított ezzel akadályt a további növekedés elé, ebben a szavazópolgárok teljes támogatását élvezve.

21 A lakóparki lakásokat nemcsak fővárosiak, hanem a magasabb státusú vidéki lakosok is megvették, akár gyerekeik számára, akár befektetési szándékkal.

22 A korábbiakban már jeleztük, hogy 2009. január 1-jén a főváros lakónépessége 1712210 fő volt. 2010. január 1-jei adatok szerint azonban Budapesten 1721556 fó élt, az agglomerációban pedig 803141 fó.

23 A demográfiai társadalmi szerkezet bemutatására ebben a tanulmányban nem volt mód terjedelmi korlátok miatt.

24 A kanadai esettel összevetve az látható, hogy az ott leírt, történetileg egymás utáni folyamatok, a fiatalok és aktívak kiáramlása, majd az idősödés a magyar esetben egy időben játszódnak le, de különböző településeken érzékelhetők. Ez részben a globális urbanizációra jellemző folyamatok követő jellegét mutatja, részben a történeti okok miatti egyedi megvalósulást.

\section{Irodalom}

Batár, A. (szerk.) (1999): Városaink az ezredfordulón. Budapest, Új Világ Kiadó (Európai füzetek; 6.))

Bronner, L. (2010): La politique de la ville impuissante á résoudre les difficultés des quartiers. Le Monde, 16 Octobre

van Criekingen, M. (2003): La ville revit! Formes, politiques et impacts de la revitalisation résidentiellea Bruxelles. In: Bidou-Zacharisen, C. (ed.): Retour en ville - des processus de "gentrification" urbaine aux politiques de "revitalisation" des centres. Descartes et Cie, Paris, 73-107.

Cattan, N., Huet, A. (2011): Urban Sprawl in the Paris Metropolitan Area (Kézirat)

Cséfalvay, Z. (2008): Kapuk, falak, sorompók, a lakóparkok világa. Gondolat-Marina Part, Budapest

Davis, M. (2007): Le pire des mondes possbiles. De l'explosion urbaine au bidonville global. La Découverte/Poche, Paris

Gill, D. (2008): Modes de vie et modes d'habiter. La banlieue québécoise, un modele de moins en moins adapté mais toujours en expansion. In: Jaumain, S., Lemarchand N. (eds.): Vivre en banlieue: une comparaison France/Canada. 53-65. (Études canadiennes-Canadian Studies; vol. 14.)

Le Goaziou, V., Rojzman, C. (2006): Les banlieues. Le Cavalier Bleu, Paris

Le Goix, R. (2004): Gated communities: Sprawl and social segregation in Southern California. http://hal.archives-ouvertes.fr/docs/00/03/58/67/PDF/legoix20041012.pdf

Fishman, R. (1990): Megalopolis Unbound. The Wilson Quarterly, 1., 25-45.

Frumkin, H. (2002): Urban Sprawl and Public Health. Public Health Reports, May-June, 201-217.

Görgl, P., Helbich, M., Matzenetter W., Fassmann, H. (2011): Spatial and Social Development Trends of Metropolitan Vienna: An Overview. (Kézirat)

Hall, P. (1996): La ville planétaire. In: Revue international des sciences sociales. Mars, 147., 19-31. 
Harter, H. (2008): La suburbanisation á Ottawa: une approche historique. In: Jaumain, S., Lemarchand N. (eds.): Vivre en banlieue: une comparaison France/Canada. 95-109. (Études canadiennes-Canadian Studies; 14.)

Howard, E. (1902): Garden Cities of To-Morrow. London

Jaumain, S., Lemarchand, N. (2008): Vivre en banlieue. Une comparaison France/Canada. Bruxelles, Bern, Berlin, Frankfurt am Main, New York, Oxford, Wien. (Études canadiennes-Canadian Studies; 14.)

Kopp, A. (1979): Architecture et mode de vie, textes de années vingt en U. R. S. S. Presses Universitaires de Grenoble

Munoz, F. (2003): Urban Sprawl in Mediterranean Cities. Cities 6., 381-385.

PESTTERV Kft. (2010): A Budapesti Agglomeráció Területrendezési Tervéről szóló 2005. évi LXIV. törvény módosításának tervezete. (Kézirat)

Reeh, H., Zerlag, M. (2011): Fairytales from the Fingerplan: Representing Strategies for Suburban Copenhagen (Kézirat)

Sassen, S. (1991): Global City: New York, London, Tokyo. Princeton University Press

Szirmai V. (1988): „Csinált” városok. Magvető Kiadó, Budapest (Gyorsuló idő sorozat)

Szirmai V. (szerk.) (2009a): A várostérségi versenyképesség társadalmi tényezői. Hogyan lehetnek a magyar nagyvárosok versenyképesebbek? Dialóg Campus Kiadó, Pécs-Budapest

Szirmai V. (2009b): A centrum-periféria modell átalakulása. In: Szirmai V. (szerk): A várostérségi versenyképesség társadalmi tényezői. Hogyan lehetnek a magyar nagyvárosok versenyképesebbek? Dialóg Campus Kiadó, Pécs-Budapest, 119-122.

Szirmai V. (2009c): A magyar történeti belvárosok társadalmi sajátosságai. In: Szirmai V. (szerk.): A várostérségi versenyképesség társadalmi tényezői. Hogyan lehetnek a magyar nagyvárosok versenyképesebbek? Dialóg Campus Kiadó, Pécs-Budapest, 43-56.

Veltz, P. (1996): Mondialisation, Villes et territoires. L'économie d'archipel, Presses Universitaires de France, Paris

Vieillard-Baron, H. (2008): La constuction de l'imaginaire banlieusard francais: entre légende noireet légende dorée. In: Jaumain, S., Lemarchand N. (eds.): Vivre en banlieue: une comparaison France/Canada. 17-32. (Études canadiennes-Canadian Studies; 14.) 17-32.

Williamson, T., Imbroscio, D., Alperovitz, G. (2005): The Challenges of Urban Sprawl. In: Kleniewsk, N. (ed.): Cities and Society. Blackwell Publishing Ltd., 303-329. 